\title{
Pengaruh Pemberian Ekstrak Taoge dan Suplemen Organik Nitrogen Aromatik Terhadap Pertumbuhan dan Perkembangan Setek Tanaman Mawar (Rosa L.)
}

\author{
Harli $^{1}$, Rasma $^{2}$ \\ Program Studi Agroteknologi Fakultas Ilmu Pertanian Universitas Al Asyariah Mandar \\ ${ }^{1}$ harli_karim@yahoo.com \\ ${ }^{2}$ Rasmathamrin65@gmail.com
}

\begin{abstract}
Abstrak
Mawar merupakan salah satu tanaman kebanggaan Indonesia dan sangat popular dimata dunia sehingga permintaan mawar terus meningkat seiring dengan meningkatnya pendapatan masyarakat, karenanya kebutuhan pasar dalam dan luar negeri pada ke nyataannya tidak dapat dipenuhi. Oleh karena itu dibutuhkan suatu teknik pembudidayaan yang diharapkan dapat menghasilkan pertumbuhan dan produksi yang maksimal sehingga kebutuhan dan permintaan akan tanaman mawar dapat dipenuhi. Penelitian Darma Kabupaten Polewali Mandar Provinsi Sulawesi Barat berlangsung dari bulan Mei sampai Juli 2016, bertujuan untuk mengetahui Pengaruh Pemberian Ekstrak Taoge dan Suplemen Organik Boom Flower Terhadap Pertumbuhan dan Perkembangan Setek Tanaman Mawar (Rosa L.). Penelitian ini dilaksanakan dengan menggunakan metode Rancangan Petak Terpisah (RPT). Petak utama pemberian ekstrak taoge (T), terdiri dari 3 taraf yaitu : T0 = Tanpa perendaman ekstrak taoge, $\mathrm{T} 1=$ Perendaman dengan ekstrak touge selama 15 menit, T2 = Perendaman dengan ekstrak taoge selama 30 menit. Anak petak penggunaan suplemen organik Boom Flower $(\mathrm{S})$, terdiri dari 3 taraf yaitu : S0 = Tanpa pemberian Boom Flower, $\mathrm{S} 1=$ Pemberian Boom Flower dengan dosis $2 \mathrm{ml} / \mathrm{l}$ air, S2 = Pemberian Boom Flower dengan dosis $4 \mathrm{ml} / \mathrm{l}$ air. Sehingga diperoleh 9 kombinasi perlakuan yang diulang sebanyak 3 kali sehingga terdapat 27 unit penelitian dan setiap perlakuan terdiri dari 2 tanaman sampel sehingga jumlah keseluruhan tanaman sebanyak 54 tanaman.Hasil penelitian menunjukkan bahwa perendaman dengan ekstrak taoge selama 30 menit (T2) memberikan pengaruh yang lebih baik terhadap waktu munculnya tunas. Dan pemberian suplemen organik Boom Flower dengan dosis $2 \mathrm{ml} / \mathrm{l}$ air (S1) memberikan pengaruh yang lebih baik terhadap waktu munculnya tunas, tinggi tunas, jumlah daun, dan waktu munculnya bunga.Tetapi tidak ada interaksi ekstrak taoge dengan suplemen organik Boom Flower yang memberikan pengaruh terbaik pada semua parameter pengamatan.
\end{abstract}

Kata Kunci : Ekstrak Tauge, Boom Flower, Setek, Mawar

\section{PENDAHULUAN}

Mawar merupakan tanaman bunga hias berupa herba dengan batang berduri. Mawar yang dikenal nama bunga ros atau ratu bunga merupakan simbol atau lambang kehidupan religi dalam peradaban manusia. Mawar merupakan simbol cinta dan kasih sayang.

Mawar merupakan salah satu tanaman kebanggaan Indonesia dan sangat popular dimata dunia karena memiliki bunga yang cantik, indah dan menarik.Selain itu memiliki nilai ekonomi dan sosial yang cukup tinggi untuk dijadikan komoditas perdagangan dan komersil.Permintaan mawar terus meningkat seiring dengan meningkatnya pendapatan masyarakat. Direktorat Jenderal Bina Produksi Hortikultura (2011), menyebutkan kebutuhan pasar dalam dan luar negeri pada kenyataannya tidak dapat dipenuhi hingga masih diperlukan impor 5-15\% dari total volume yang dibutuhkan. Bahkan, sejak 10 tahun terakhir permintaan akan bunga atau tanaman hias meningkat pesat dari tahun ke tahun, di kotakota besar tercatat lebih dari 50 juta tangkai bunga atau tanaman bunga potong dibutuhkan setiap tahun untuk mencukupi permintaan pasar ibu kota.

Boom Flower merupakan suplemen tanaman yang mengandung Nitrogen Aromatik (aromatik N) yang bisa langsung diserap oleh tanaman. Aromatik bentuk nitrogen yang unik mendorong pertumbuhan tanaman yang sehat dan keseimbangan hormon tanaman normal pada tingkat aplikasi relatif rendah dan meningkatkan hasil

Dengan melihat kandungan, manfaat, nilai estetika, faktor kebutuhan dan permintaan pasar akan 
tanaman mawar, maka dibutuhkan suatu teknik pembudidayaan yang diharapkan dapat menghasilkan pertumbuhan dan produksi yang maksimal sehingga dapat memenuhi kebutuhan dan permintaan tanaman. Menurut Djamal (2012), pertumbuhan tanaman ditentukan oleh pupuknya, sementara arah dan kualitas dari pertumbuhan dan perkembangan sangat ditentukan oleh zat pengatur tumbuh. Pemberian zat pengatur tumbuh yang tepat, baik komposisi dan konsentrasinya, dapat mengarahkan pertumbuhan dan perkembangan tanaman menjadi lebih baik. Zat pengatur tumbuh (ZPT) adalah senyawa organik bukan hara tetapi dapat merubah proses fisiologis tumbuhan. Seringkali pemasokan zat pengatur tumbuh secara alami berada dibawah optimal dan dibutuhkan sumber dari luar untuk menghasilkan respon yang dikehendaki.

Zat pengatur tumbuh yang biasa digunakan saat ini adalah zat pengatur tumbuh sintetik yang harganya relatif mahal dan kadang langka ketersediaannya. Untuk mengatasi hal ini perlu dipikirkan zat pengatur tumbuh yang dapat diperoleh dengan mudah, murah namun memiliki kemampuan yang sama atau lebih dari zat pengatur tumbuh sintetik. ZPT (Auksin,Giberilin,Sitokinin) dapat diekstrak dari senyawa bioaktif tanaman. Ekstraksi senyawa bioaktif tanaman dapat dilakukan pada kecambah kacang hijau. Kecambah kacang hijau (taoge) merupakan jenis sayuran yang umum dikonsumsi, mudah diperoleh, ekonomis, dan tidak menghasilkan senyawa yang berefek toksik (Apriska Fildzah, et., al, 2015).

\section{METODE PENELITIAN}

Penelitian ini dilaksanakan di UPTD Hortikultura Darma Kabupaten Polewali Mandar yang berlangsung pada bulan mei sampai juli 2016. Penelitian ini dilakukan dengan menggunakan Rancangan Petak Terpisah (RPT). Petak utama adalah pemberian ekstrak taoge kacang hijau dengan 3 taraf yaitu :T0 = Kontrol (tanpa perendaman ekstrak taoge), $\mathrm{T} 1=$ Perendaman dengan ekstrak taoge selama 15 menit, $\mathrm{T} 2=$ Perendaman dengan ekstrak taoge selama 30 menit. Anak petak adalah penggunaan suplemen organik boom flower yang terdiri atas 3 taraf yaitu : S0 = Kontrol (tanpa pemberian boom flower), $\mathrm{S} 1=$ Pemberian boom flower dengan dosis $2 \mathrm{ml} / \mathrm{I}$ air, $\mathrm{S} 2=$ Pemberian boom flower dengan dosis $4 \mathrm{ml} / \mathrm{l}$ air, sehingga diperoleh 9 kombinasi perlakuan. Setiap perlakuan diulang sebanyak 3 kali sehingga terdapat 27 unit penelitian dan setiap perlakuan terdiri dari 2 tanaman sampel sehingga jumlah keseluruhan tanaman sebanyak 54 tanaman.

\section{HASIL DAN PEMBAHASAN}

Sidik ragam menunjukkan bahwa perendaman dengan ekstrak taoge (T) memberikan pengaruh nyata dan pemberian suplemen organik boom flower (S) berpengaruh sangat nyata, tapi interaksinya tidak memberikan pengaruh nyata terhadap waktu munculnya tunas bunga mawar.

Tabel 1. Rata-rata Waktu Muncul Tunas (hari) pada Pemberian Ekstrak Taoge dan Suplemen Organik Terhadap Setek Tanaman Mawar

\begin{tabular}{cccccc}
\hline \multirow{2}{*}{$\begin{array}{c}\text { Lama } \\
\text { Perendaman }\end{array}$} & S0 & S1 & S3 & $\begin{array}{c}\text { Rata- } \\
\text { rata }\end{array}$ & $\begin{array}{c}\text { UJBD } \\
\text { a 0,05 }\end{array}$ \\
\cline { 2 - 6 } & 26,00 & 23,00 & 24,67 & $24,56^{\mathrm{a}}$ & 1,32 \\
T0 & 24,83 & 21,33 & 23,33 & $23,16^{\mathrm{b}}$ & 1,39 \\
T2 & 23,17 & 21,33 & 23,00 & $22,50^{\mathrm{b}}$ & \\
\hline Rata-Rata & $24,67^{\mathrm{a}}$ & $21,89^{\mathrm{b}}$ & $23,67^{\mathrm{b}}$ & & \\
\hline NP.UJBD & 2,13 & 2,24 & & & \\
a 0,01 & & & & \\
\hline
\end{tabular}

Angka-angka yang diikuti oleh huruf yang berbeda berarti berbeda nyata pada Uji Jarak Berganda Duncan Taraf a 0,05dan a 0,01

Berdasarkan UJBD taraf a 0,05 dan a 0,01 pada Tabel 1 menunjukkan bahwa lama perendaman setek dengan ekstrak taoge selama 30 menit (T2) berpengaruh lebih baik dan berbeda nyata dibandingkan dengan tanpa perendaman setek dengan ekstrak taoge (T0),tetapi tidak berbeda dengan lama perendaman setek dengan ekstrak taoge selama 15 menit (T1) terhadap waktu munculnya tunas bunga mawar.

Demikian pula dengan pemberian suplemen organik boom flower dengan dosis $2 \mathrm{ml} / \mathrm{l}$ air (S1) memberikan pengaruh lebih baik dan berbeda sangat nyata dibandingkan dengan tanpa pemberian suplemen organik boom flower (S0), tetapi tidak berbeda dengan pemberian suplemen organik boom flower dengan dosis $4 \mathrm{ml} / \mathrm{l}$ air (S2) terhadap waktu munculnya tunas bunga mawar.

Parameter tinggi tunas menunjukkan bahwa pemberian suplemen organik boom flower (S) memberikan pengaruh sangat nyata. Sedangkan perendaman dengan ekstrak taoge (T) dan interaksinya memberikan pengaruh tidak nyata. 
Tabel 2. Rata-rata Tinggi Tunas (cm) pada Pemberian Ekstrak Taoge

dan Suplemen Organik Terhadap Setek Tanaman Mawar

\begin{tabular}{ccccc}
\hline \multirow{2}{*}{$\begin{array}{c}\text { Lama } \\
\text { Perendaman }\end{array}$} & S0 & S1 & S3 & $\begin{array}{c}\text { Rata- } \\
\text { rata }\end{array}$ \\
\cline { 2 - 5 } & $24,05^{\mathrm{a}}$ & $25,10^{\mathrm{a}}$ & $24,47^{\mathrm{a}}$ & 24,54 \\
T0 & $23,80^{\mathrm{a}}$ & $25,55^{\mathrm{a}}$ & $24,20^{\mathrm{a}}$ & 24,52 \\
T1 & $23,57^{\mathrm{a}}$ & $27,30^{\mathrm{b}}$ & $24,78^{\mathrm{c}}$ & 24,87 \\
\hline T2 & 23,81 & 25,98 & 24,48 & \\
\hline Rata-Rata & 2,39 & 2,51 & & \\
NP.UJBD & & & \\
\hline
\end{tabular}

Angka-angka yang diikuti oleh huruf yang berbeda berarti berbeda nyata pada Uji Jarak Berganda Duncan Taraf a 0,05dan a 0,01

Berdasarkan UJBD taraf a 0,01 pada Tabel 2 menunjukkan bahwa pemberian suplemen organik boom flower dengan dosis $2 \mathrm{ml} / \mathrm{l}$ air (S1) memberikan pengaruh lebih baik dan berbeda sangat nyata dibandingkan dengan tanpa pemberian suplemen organik boom flower (S0) dan lebih baik dan berbeda sangat nyata dibandingkan dengan pemberian suplemen organik boom flower dengan dosis $4 \mathrm{ml} / \mathrm{l}$ air (S2) terhadap tinggi tunas bunga mawar.

Sidik ragam menunjukkan bahwa pemberian suplemen organik boom flower (S) memberikan pengaruh sangat nyata.Sedangkan perendaman dengan ekstrak taoge (T) dan interaksinya memberikan pengaruh tidak nyata terhadap jumlah daun bunga mawar.

Tabel 3. Rata-rata Jumlah Daun (helai) pada Pemberian Ekstrak Taoge dan Suplemen Organik Terhadap Setek Tanaman Mawar

\begin{tabular}{ccccc}
\hline \multirow{2}{*}{$\begin{array}{c}\text { Lama } \\
\text { Perendaman }\end{array}$} & S0 & S1 & S3 & $\begin{array}{c}\text { Rata- } \\
\text { rata }\end{array}$ \\
\cline { 2 - 5 } T0 & 27,67 & 83,33 & 64,33 & 58,43 \\
T1 & 34,00 & 90,17 & 71,83 & 65,33 \\
T2 & 42,67 & 93,50 & 80,33 & 72,17 \\
\hline & & & \\
Rata-Rata & $34,78^{\mathrm{a}}$ & $89,00^{\mathrm{b}}$ & $72,16^{\mathrm{b}}$ & \\
\hline & & & \\
\hline $\begin{array}{l}\text { NP.UJBD } \\
\text { a 0,01 }\end{array}$ & 38,07 & 40,10 \\
\hline Angka-angka yang diikuti oleh huruf yang berbeda \\
berarti berbeda nyata pada Uji Jarak Berganda \\
Duncan Taraf a 0,05dan a 0,01
\end{tabular}

Berdasarkan UJBD taraf a 0,01 pada Tabel 3 menunjukkan bahwa pemberian suplemen organik boom flower dengan dosis $2 \mathrm{ml} / \mathrm{l}$ air (S1) memberikan pengaruh lebih baik dan berbeda sangat nyata dibandingkan dengan tanpa pemberian suplemen organik boom flower (S0), tetapi tidak berbeda dengan pemberian suplemen organik boom flower dengan dosis $4 \mathrm{ml} / \mathrm{l}$ air (S2) terhadap jumlah daun bunga mawar.

Agrovital | Jurnal Ilmu Pertanian Universitas Al Asyariah
Sidik ragam menunjukkan bahwa pemberian suplemen organik boom flower (S) memberikan pengaruh sangat nyata.Sedangkan perendaman dengan ekstrak taoge (T) dan interaksinya memberikan pengaruh tidak nyata terhadap waktu munculnya bunga pada bunga mawar.

Tabel 4. Rata-rata Waktu Munculnya Tunas (hari) pada Pemberian Ekstrak Taoge dan Suplemen Organik Terhadap Setek Tanaman Mawar

\begin{tabular}{ccccc}
\hline \multirow{2}{*}{$\begin{array}{c}\text { Lama } \\
\text { Perendaman }\end{array}$} & S0 & S1 & S3 & $\begin{array}{c}\text { Rata } \\
\text {-rata }\end{array}$ \\
\cline { 2 - 5 } T0 & 86,17 & 67,33 & 78,17 & $\begin{array}{c}76,8 \\
8\end{array}$ \\
T1 & 81,33 & 57,17 & 59,67 & $\begin{array}{c}64,8 \\
4\end{array}$ \\
T2 & 84,67 & 55,67 & 56,17 & $\begin{array}{c}63,5 \\
0\end{array}$ \\
\hline Rata-Rata & $\begin{array}{c}84,06 \\
\mathrm{a}\end{array}$ & $\begin{array}{c}60,06 \\
\mathrm{~b}\end{array}$ & $64,66^{\mathrm{b}}$ & \\
\hline $\begin{array}{l}\text { NP.UJBD } \\
\text { a 0,01 }\end{array}$ & 22,30 & 23,49 & & \\
\hline
\end{tabular}

Angka-angka yang diikuti oleh huruf yang berbeda berarti berbeda nyata pada Uji Jarak Berganda Duncan Taraf a 0,05dan a 0,01

Berdasarkan UJBD taraf a 0,01 pada Tabel 4 menunjukkan bahwa pemberian suplemen organik boom flower dengan dosis $2 \mathrm{ml} / \mathrm{l}$ air (S1)memberikan pengaruh lebih baik dan berbeda sangat nyata dibandingkan dengan tanpa pemberian suplemen organik boom flower (S0), tetapi tidak berbeda dengan pemberian suplemen organik boom flower dengan dosis $4 \mathrm{ml} / \mathrm{l}$ air (S2)terhadap waktu munculnya bungapada bunga mawar.

\section{KESIMPULAN}

1. Perendaman dengan ekstrak taoge selama 30 menit (T2) memberikan pengaruh yang lebih baik pada waktu munculnya tunas.

2. Pemberian suplemen organik Boom Flower dengan dosis $2 \mathrm{ml} / \mathrm{l}$ air (S1) memberikan pengaruh yang lebih baikpadawaktu munculnya tunas, tinggi tunas, jumlah daun dan waktu munculnya bunga.

3. Tidak ada interaksi ekstrak taoge dengan suplemen organik Boom Flower yang memberikan pengaruh terbaik pada semua parameter pengamatan. 


\section{DAFTAR PUSTAKA}

Arya Arnadi, $2010 . \quad$ Morfologi mawar.http://documents.tips/dokuments/ morfologi_mawar.html. Diakses pada tanggal 27 November 2015

Eko Purdyaningsih, 2013. Kajian Pengaruh Pemberian ZPT Terhadap Pertumbuhan Setek Nilam. Balai Besar Perbenihan dan Proteksi Tanaman Perkebunan

Dalam Fildzah Apriska, 2015. Respon pertumbuhan propagul pisang barangan pada beberapa konsentrasi ekstrak kecambah kacang hijau secara in vitro.(Skripsi). Universitas Hasanuddin, Makassar

Dirjen Bina Produksi Hortikultura, 2011. Dalam Saefudin Tete dan Ayasha Ivonne, 2014. Analisis Rantai Pasokan Komoditas Florikultura Sebagai Upaya Peningkatan Ekonomi Masyarakat Di Kabupaten Bandung. Universitas Pasundan, Bandung

Djamal, 2012. Dalam Leovici Helena, 2013. Pengaruh macam dan konsentrasi bahan organik sebagai sumber zat pengatur tumbuh alami terhadap pertumbuhan bubit tebu. (Skripsi). Universitas Gadja Mada, Yogyakarta

Edhi Sandra, 2011. Hormon dan pertumbuhan tanaman.http://eshaflora.blogspot.co.id/2011/04 /hormon-dan-pertumbuhan-tanaman.html. Diakses pada tanggal 27 November 2015

Frenkikurniawan, 2013.Klasifikasi dan morfologi bunga

mawar.http://blogspot.com/klasifikasi_dan_mor fologi_bunga_mawar.html.Diakses_pada tanggal 27 November 2015

Flori, 2009. Dalam Perpustakaan. Budidaya tanaman hias mawar pot Desa Cihideng, Kec.Parompong, Kab.Bandung Barat. Universitas Pendidikan Indonesia, Bandung

Gardner, et.al., 1991. Dalam Leovici Helena, 2013. Pengaruh macam dan konsentrasi bahan organik sebagai sumber zat pengatur tumbuh alami terhadap pertumbuhan bibit tebu. (Skripsi). Universitas Gadja Mada, Yogyakarta

Gunawan, 2009. Dalam Ulfa Fachira, 2013. Peran Senyawa Bioaktif Tanaman Sebagai ZPT Dalam Memacu Produksi Umbi Mini Kentang Pada Sistem Budidaya Aeroponik.(Skripsi). Universitas Hasanuddin, Makassar

Hartmann dan Kester, 1975.Dalam Suprapto Agus, 2004. Auksin: Zat Pengatur Tumbuh Penting Meningkatkan Mutu Setek Tanaman. Universitas Tidar Magelang, Magelang.

Iqbal Aditya, 2010. Pengaruh ekstrak taoge terhadap kerusakan sel ginjal mencit yang diinduksi
parasetamol.(Skripsi). Universitas Sebelas Maret, Surakarta

Jones, Jr. et al, 1991. Padi. Universitas Sumatera Utara

Lawlor, 1987, cit. Gardner et al., 1991. Dalam Sulistyaningsih Endang, et al.,2005.Pertumbuhan dan hasil caisin pada berbagai warna sungkup plastik.Universitas Gadjah Mada, Yogyakarta

Leopold, 1963. Dalam Eko Purdyaningsih, 2013. Kajian Pengaruh Pemberian ZPT Terhadap Pertumbuhan Setek Nilam. Balai Besar Perbenihan dan Proteksi Tanaman Perkebunan

Otazu Victor, 2010. Dalam Ulfa Fachira, 2013. Peran Senyawa Bioaktif Tanaman Sebagai ZPT Dalam Memacu Produksi Umbi Mini Kentang Pada Sistem Budidaya Aeroponik.(Skripsi). Universitas Hasanuddin, Makassar

PT.Bina Guna Kimia (FMC), 2014.Boom flower. Jakarta

Riyadi, 2014.Penggunaan Zat Pengatur Tumbuh dan Bahan-Bahan Lain. Materi disampaikan pada pelatihan kultur jaringan tanaman perkebunan. BPBPI, Bogor

Rukmana, 1995. Dalam Sarce, 2015. Respon Pertumbuhan Stek Mawar (Rosa sp) Pada Lama Perendaman Hormon Tumbuh Harmonik dan Berbagai Konsentrasi Media Tanam.(Skripsi tidak dipublikasikan). Unasman, Polman

Salisbury, 1995. Peranan gelombang cahaya dalam fotosintesis.www.academia.edu/9518031/cahay a. Diakses pada tanggal 2 Desember 2015

Salisbury dan Ross, 1995.Kultur jaringan tanaman.Spesialisplantae.Blogspot.co.id/2016/0 1/kultur_jaringan_tanaman.html.Diakses pada tanggal 2 Desember 2015

Suyamto, et.al., 2005. Dalam Ulfa Fachira, 2013. Peran Senyawa Bioaktif Tanaman Sebagai ZPT Dalam Memacu Produksi Umbi Mini Kentang Pada Sistem Budidaya Aeroponik. (Skripsi).Universitas Hasanuddin, Makassar

Santi, 2007. Dalam Sarce, 2015. Respon Pertumbuhan Stek Mawar (Rosa sp) Pada Lama Perendaman Hormon Tumbuh Harmonik dan Berbagai Konsentrasi Media Tanam.(Skripsi tidak di publikasikan). Unasman, Polman

Shahab, et al., 2009; Zhao, 2010. Dalam Kastono Dody, et.al., 2014. Pengaruh macam dan konsentrasi bahan organik sumber zat pengatur tumbuh alami terhadap pertumbuhan awal tebu. Universitas Gadjah Mada, Yogyakarta

Tidar Ardiyanto, 2013. Boom Flower (2).http://tidar19.Blogspot.co.id/2013/10/boomflower-2.htmlDiakses pada tanggal 19 Januari 2017 
Tim Karya Tani Mandiri, 2010:11, 12-13, 27, 29. Mawar.Lumbung Pustaka UNY, Yogyakarta Wattimena, 1987. tanaman.Spesialisplantae.blogspot.co.id/2016/0 1/kultur_jaringan tanaman.html. Diakses pada tanggal 2 Desember 2015 